\title{
KOSAKATA SISWA SEKOLAH DASAR KELAS RENDAH (KAJIAN JENIS KATA, BENTUK KATA, JENIS MAKNA, DAN MEDAN MAKNA)
}

\author{
Yeti Mulyati
}

\author{
Universitas Pendidikan Indonesia
}

\begin{abstract}
This study aimed to describe the vocabulary of low grade primary school students based on the type and form of the word, and also the type and semantics domain. Source of research data is in the form of students written language derived from the essays of graders 2 and 3 from 6 elementary schools in Bandung. The data were analyzed qualitatively. The results showed: 1) the type of words made up of nouns $(37 \%)$, verbs $(35 \%)$, adverbial (10\%), function words $(9 \%)$, pronouns $(5 \%)$, numeralia $(3 \%)$, and adjectives $(1 \%) ; 2$ ) forms of words consist of basic words $(62 \%)$, derivational words $(28 \%)$, particle $(0.8 \%)$, reduplicative words $(0.2 \%)$, compound words, $(0.01)$; 3 ) classification of the meaning consists of referential meaning (87\%) and nonreferential meaning (13\%); and 4) semantics domain include: motion-employment (29\%), function words (13\%), personal pronouns /reference $(10 \%)$, nature $(7 \%)$, tempe-rament/properties/color $(5 \%)$, animals ( $4.7 \%)$, the life of the community $(4.6 \%)$, games $(2.7 \%)$, home/parts $(2.4 \%)$, numeral words $(2.3 \%)$, food/beverages (1.8\%), body parts (1.4\%), disease-treatment $91.3 \%)$.
\end{abstract}

Keywords: vocabulary, part of speech, form of the words, type of meaning, semantics domain

\begin{abstract}
Abstrak: Penelitian ini bertujuan untuk memerikan kosakata siswa kelas rendah sekolah dasar berdasarkan jenis dan bentuk kata, jenis dan medan makna. Sumber data penelitian ini berupa bahasa tulis siswa yang dijaring dari karangan siswa kelas 2 dan 3 dari 6 SD di Kota Bandung. Analisis data dilakukan secara kualitatif. Hasil penelitian menunjukkan: 1) jenis kata terdiri atas nomina (37\%), verba $(35 \%)$, adverbial (10\%), kata tugas (9\%), pronomina (5\%), numeralia (3\%), dan adjektiva $(1 \%) ; 2)$ bentuk kata terdiri atas kata dasar (62\%), kata berimbuhan $(28 \%)$, klitik $(0.8 \%)$, kata ulang $(0.2 \%)$, kata majemuk, $(0,01) ; 3)$ klasifikasi makna terdiri atas makna bereferensial (87\%) dan makna nonreferensial (13\%); dan 4) medan makna meliputi: gerak-kerja (29\%), kata tugas (13\%), kata ganti sapaan/acuan (10\%), alam (7\%), perangai/sifat/warna (5\%), binatang $(4,7 \%)$, kehidupan masyarakat $(4.6 \%)$, permainan $(2.7 \%)$, rumah/bagian-bagiannya $(2,4 \%)$, kata bilangan $(2,3 \%)$, makanan/minuman $(1,8 \%)$, bagian tubuh $(1,4 \%)$, penyakit-pengobatan $91,3 \%)$.
\end{abstract}

Kata Kunci: kosakata, jenis kata, bentuk kata, jenis makna, medan makna

Setiap anak akan mengalami proses perkembangan dan pemerolehan bahasa, sejak dilahirkan hingga perkembangan selanjutnya. Oleh karena itu, perkembangan dan pemerolehan bahasa berlaku pada siapa saja di muka bumi ini. Pemerolehan bahasa itu bersifat universal. Menurut Dardjowidjojo (2010:218), sebelum mencapai umur 12 tahun, 
anak mempunyai kemampuan untuk memperoleh bahasa mana pun yang disajikan padanya secara naratif. Konsep demikian itu disebut "Hipotesis Umur Kritis" (Critical Age Hypothesis). Esensi dari hipotesis ini adalah bahwa antara umur 2 sampai 12 tahun, seorang anak dapat memperoleh kemampuan bahasa mana pun dengan kemampuan menyamai seorang penutur asli.

Dalam kaitannya dengan perkembangan kosakata, Labov dan Fishman menyatakan bahwa semakin tinggi usia seseorang maka akan semakin banyak kata yang dikuasainya. Ini menunjukkan bahwa bahasa yang dimiliki oleh setiap manusia akan berkembang sepanjang hidupnya, mulai dari lahir hingga akhir hayatnya, seiring dengan bertambahnya usia dan kematangan jiwanya. Bahasa anak berkembang seiring dengan perkembangan intelektualnya. Suatu kegiatan berpikir tidak dapat terjadi tanpa menggunakan bahasa. Vigotsky (dalam Zuchdi dan Budiasih, 1996:5) menyatakan bahwa bahasa merupakan dasar bagi pembentukan konsep dan pikiran. Bahasa memiliki korelasi yang kuat dengan kegiatan berpikir. Oleh karena itu perkembangan bahasa memiliki keterkaitan dengan perkembangan intelektual anak.

Bahasa memiliki hal yang sifatnya universal yang terdapat pada bahasa apa pun di dunia (Vladimir dan Petrova, 2015). Dardjowidjojo (2010:230) menyarikan hasil riset Geenberg (1963) mengenai "universal bahasa" yang berhasil memilah-milah bahasa ke dalam fitur-fitur berikut: (a) fitur yang dimiliki oleh semua bahasa, (b) fitur yang dimiliki kebanyakan bahasa, dan (c) fitur yang dimiliki oleh beberapa bahasa. Konsep tersebut diperjelas oleh Comrie (1989) yang membagi universal menjadi dua klasifikasi, yakni (a) absolut dan (b) tendensius, yang keduanya bersifat non-implikasional dan implikasional. Bahwa semua bahasa memiliki bunyi vokal yang berpotensi membentuk suku kata dan atau kata merupakan contoh keuniversalan bahasa absolut non-implikasional. Jika suatu bahasa mengenal bunyi hambat pada konsonan bilabial, maka hal serupa terjadi pula pada bunyi hambat lainnya. Hal ini merupakan contoh dari absolut implikasional. Contoh tendensius non-implikasional tampak pada bunyi nasal yang hampir dimliki oleh semua bahasa. Sementara yang bersifat implikasional tampak pada peluang-peluang kaidah suatu bahasa yang didasarkan atas sebuah pola atau kaidah tertentu.

Chomsky (1999) membedakan konsep universal itu ke dalam dua klasifikasi, yakni (a) universal substantif, dan (b) universal formal. Universal substantif berkaitan dengan elemen yang membentuk bahasa, seperti nomina, verba, adjektiva. Sementara universal formal berkaitan dengan cara bagaimana universal substantif itu diatur, yang tentu saja akan berbeda antara satu bahasa dengan bahasa lainnya. Manusia mempunyai apa yang oleh Chomsky disebut faculties of the mind, yakni semacam kapling-kapling intelektual dalam benak/otak seseorang, dan salah satu kaplingnya itu adalah kapling bahasa. Dalam kaitannya dengan kapling universal bahasa, Chomsky berpendapat bahwa setiap manusia memiliki kapling kodrati yang dibawa sejak lahir, yang disebutnya sebagai Language Acquisition Device (LAD) atau "Piranti Pemerolehan Bahasa" (Dardjowijoyo, 2010: 232).

Penguasaan kosakata siswa akan berjenjang sesuai dengan taraf perkembangan usianya (Roberts. 2014:23-24). Demikian juga dengan kosakata anak usia sekolah dasar, baik yang masih tergolong siswa kelas rendah (1-3 SD), maupun siswa kelas tinggi (4-6 SD). Bagaimana karakteristik kosakata siswa sekolah dasar, khususnya kosakata siswa SD kelas rendah (yang berusia sekitar 7-9 tahun) merupakan fokus utama dari kajian ini. Hasil penelitian ini diharapkan dapat menjadikan bahan pertimbangan bagi para praktisi pendidikan dalam pengelolaan proses belajar mengajar, seperti bagaimana memilih bahan 
ajar, menulis buku ajar, memilih diksi yang tepat untuk berinteraksi dalam proses belajar mengajar.

Terdapat empat tujuan yang diungkap melalui penelitian ini, yakni memerikan kosakata siswa SD kelas rendah dari sisi :(a) jenis kata, (b) bentuk kata, (c) jenis makna, dan (d) medan makna. Konsep kata dalam penelitian ini merujuk pada konsep kata sebagaimana yang dijelaskan dalam KBBI (online 2016), Alwi (2003: 76), Ramlan (1985: 29); dan Chaer (2009: 37). Pada dasarnya kata didefinisikan sebagai satuan bahasa yang memiliki satu pengertian; deretan huruf yang diapit oleh dua buah spasi, dan mempunyai satu arti. Secara gramatikal, kata mempunyai dua status, yaitu (1) sebagai satuan terbesar dalam tataran morfologi, dan (2) satuan terkecil dalam tataran sintaksis. Sebagai satuan terbesar dalam tataran morfologi, kata dibentuk dari bentuk dasar (yang dapat berupa morfem dasar terikat maupun bebas, atau gabungan morfem) melalui proses morfologis berikut: afiksasi, reduplikasi, atau komposisi. Sebagai satuan terkecil dalam sintaksis, kata khususnya yang termasuk kelas terbuka (nomina, verba, dan ajektiva) dapat mengisi fungsi-fungsi sintaksis.

Chaer (2007:166) mengklasifikasikan kata berdasarkan paham tradisional dan paham struktural. Menurut pandangan tradisional, pengelompokan kata didasarkan atas dua kriteria, yaitu kriteria makna dan kriteria fungsi. Kriteria makna digunakan untuk mengidentifikasi kelas verba, nomina, dan adjektiva; sedangkan kriteria fungsi digunakan untuk mengidentifikasi preposisi, konjungsi, adverbia, pronomina, dsb. Pengklasifikasian kata menurut pandangan strukturalis didasarkan pada distribusi kata itu dalam suatu struktur atau konstruksi. Pengklasifikasian kata didasarkan pada bentuk dan kelas kata. Berdasarkan bentuknya, kata terbagi menjadi empat, yakni: kata dasar, kata turunan, kata ulang, dan kata majemuk. Berdasarkan kelasnya, kata terbagi menjadi tujuh jenis yakni: nomina, verba, adjektiva, adverbia, pronomina, numeralia, dan kata tugas (lihat juga Wasik, 2016).

\section{METODE PENELITIAN}

Penelitian ini menggunakan pendekatan deskriptif-kualitatif dalam perspektif pendekatan struktural dalam mengamati objek bahasa. Data penelitiannya berupa kata-kata yang dijaring melalui bahasa tulis siswa sekolah dasar yang duduk di bangku kelas rendah (2-3 SD) di Kota Bandung. Data diambil dari 99 karangan siswa kelas 2 dan 3 SD (kelas rendah) di kota Bandung, yakni SD Istiqomah Ciliwung, SD Bina Talenta, SD Sukagalih 7, SDN Cipamokolan, dan SDN Margahayu Utara.

Teknik analisis data dilakukan secara deskriptif-kualitatif dengan langkah-langkah sebagai berikut: (1) melakukan pengkodean terhadap setiap data karangan, (2) mendaftar dan memindahkan kata-kata yang terdapat dalam sumber data ke dalam kartu-kartu kata, (3) menandai dan mengelompokkan data berdasarkan dugaan kesamaan/kemiripan karakteristk; (4) menganalisis setiap kata dengan berpedoman pada kartu analisis data yang berisi parameter analisis, (5) melakukan analisis silang data di antara 3 orang penganalisis untuk memastikan ketepatan hasilanalisis, (5) melakukan klarifikasi dan konfirmasi jika ditemukan hasil yang jomplang dalam analisis data, (6) melakukan penafsiran terhadap hasil analisis data, dan (7) menyimpulkan hasil analisis data berupa pemerian fokus kajian dan hasil kuantifikasinya. 


\section{HASIL DAN PEMBAHASAN}

\section{Kosakata Siswa Kelas Rendah Berdasarkan Aspek Jenis Kata}

Berdasarkan jenis katanya, kosakata siswa SD kelas rendah menunjukkan hasil sebagaimana tampak dalam diagram 2.

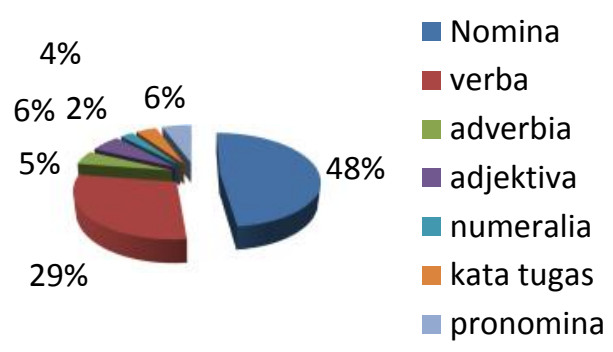

\section{Diagram 1. Jenis kata Siswa SD}

Dalam diagram 1, tampak kelas kata nomina merupakan kata yang paling dominan digunakan anak sekolah dasar di kelas rendah disusul dengan verba. Yang paling sedikit adalah kelas kata numeralia. Berdasarkan temuan ini yang dikaitkan dengan konsep keuniversalan bahasa, terdapat beberapa hasil penelitian terdahulu yang disitir oleh Dardjowidjojo (2010) terdukung oleh hasil penelitian ini. Temuan-temuan penelitian terdahulu itu antara lain: (a) dalam subkomponen morfologi, afiks infleksional cenderung dikuasai lebih dahulu daripada afiks derivasional (Periksa Petters, 1995); (b) anak-anak terlebih dahulu menguasai nomina sebelum verba (Gentner, 1982, Bloom, dkk., 1993; Tardif, 1996); (c) dalam hal semantik, keuniversalan kosakata anak mengacu pada prinsip here and now, yakni anak-anak akan menguasai objek yang ada di sekelilingnya (here) dan yang saat ini (now); (d) kemampuan anak dalam aspek komprehensi lima kali lipat lebih tinggi bila dibandingkan dengan kemampuan produksinya (Benedict, 1979), sementara temuan Fenson, dkk (2001) adalah pada saat anak dapat memproduksi 10 kata, maka tingkat komprehensinya 11 kali lipat dari itu, dari 10 jadi 110 kata.

Perkembangan pragmatik merupakan fase paling penting dalam perkembangan bahasa anak pada usia sekolah. Pragmatik dapat dimaknai sebagai penggunaan bahasa yang sesungguhnya dalam konteks nyata (language use). Anak-anak usia 5-6 tahun berpotensi untuk menghasilkan cerita. Mereka dapat mengungkapkan pikiran dan perasaannya ke dalam bentuk cerita. Pada umumnya cerita yang mereka hasilkan berupa cerita yang erat kaitan dengan kehidupan sehari-hari, misalnya lingkungan tempat mereka tinggal. Pada saat anak-anak memasuki kelas dua sekolah dasar, anak-anak dapat bercerita dengan menggunakan kalimat yang lebih panjang dengan menggunakan konjungsi: dan, lalu, dan kata depan: di, ke, dan dari. Pada umumnya, plot yang disusunnya menjadi sebuah cerita masih belum jelas. Oleh karena itu, seringkali dijumpai lompatan-lompatan pikiran, lompatan ide, yang belum terssusun secara sistematis dan kronologis.

Pada saat anak memasuki usia tujuh tahun, anak dapat membuat cerita yang lebih teratur. Mereka dapat menyusun cerita dengan cara mengemukakan masalah, rencana pemecahan masalah, dan menyelesaikan masalah. Pada usia delapan tahun, mereka dapat menggunakan kalimat pembuka dan penutup cerita, misalnya dengan menggunakan "Pada suatu ...." dan di akhir cerita menggunakan "Akhirnya ....". Selain itu, anak sudah dapat 
menemukan tokoh yang dapat mengatasi masalah yang ada dalam cerita yang dibaca atau didengarnya.

\section{Kosakata Siswa Kelas Rendah Berdasarkan Aspek Bentuk Kata}

Berdasarkan bentuk katanya, kosakata siswa kelas rendah sekolah dasar memperlihatkan imbangan persentase seperti diagram 2 .

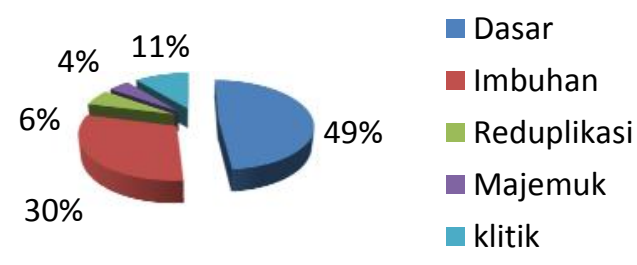

\section{Diagram 2. Bentuk kata Siswa SD}

Produksi kata dasar mendominasi kosakata siswa kelas rendah dibandingkan bentuk kata lainnya. Beberapa ahli keterbacaan seperti Rudolp Franz Flesh, Edward Fry, Alton L. Raygor, yang telah menghasilkan beberapa alat ukur keterbacaan teks mendasarkan pertimbangan tingkat kesulitan teks pada dua hal (Harjasujana \& Mulyati, 1995), yakni (a) panjang pendek kata, dan (b) panjang-pendek kalimat. Artinya, setiap satuan lingual kata atau kalimat dipandang memiliki tingkat kesulitan yang tinggi jika berwujud panjang (dibentuk oleh lebih banyak lambang huruf dalam membentuk kata dan lebih banyak kata dalam membentuk kalimat). Berdasarkan asumsi ini, bentuk-bentuk kata dasar memiliki tingkat kesulitan yang lebih mudah jika dibandingkan dengan bentuk-bentuk lainnya, seperti kata berimbuhan (berafiks), kata ulang (reduplikasi), atau kata majemuk (kompositum).

Bagaimana halnya dengan klitik? Dari sisi wujud, klitik ditulis menyatu dengan bentukan yang diikutinya. Secara kasat mata, kata-kata yang mengandung klitik tentu akan lebih kompleks wujudnya daripada kata/bentuk dasar. Hal ini memperkuat konsep alat-alat ukur keterbacaan wacana sebagaimana yang disodorkan para ahli tadi.Bentukan kelinciku lebih sulit bila dibandingkan dengan kelinci aku bagi pembaca-pembaca pemula.

Menurut teori perkembangan bahasa anak, M. Schaerlaekens (1977) seperti disitir oleh Mar'at (2005: 61-68), siswa SD kelas rendah berada pada periode sesudah 5 tahun. Karakteristik utama pada periode ini ialah anak-anak menunjukkan kemajuan dalam kosakata, membuat kalimat lengkap, menguasai kategori-kategori linguistik yang lebih kompleks, dan memahami hal-hal yang bersifat abstrak. Temuan Benedict (1979) menunjukkan bahwa kemampuan anak dalam aspek komprehensi lima kali lipat lebih tinggi bila dibandingkan dengan kemampuan produksinya. Artinya, kemampuan reseptif anak terhadap stimulus bahasa jauh lebih besar ketimbang apa yang dapat dilahirkannya. Bahkan Fenson, dkk (2001) memberikan bandingan antara kemampuan produksi dan komprehensinya adalah 1:11. Artinya, dari 10 kata yang diproduksi, potensi kemampuan tingkat komprehensinya menjadi 110 kata. 


\section{Kosakata Siswa Kelas Rendah Berdasarkan Aspek Klasifikasi Jenis Makna}

Berdasarkan klasifikasi jenis maknanya, kosakata terbagi dua kategori, yakni kata-kata yang memiliki makna referensial dan kata-kata nonreferensial. Pengklasifikasian jenis makna ini didasarkan atas ada tidaknya acuan yang dirujuk oleh suatu satuan lingual tertentu terhadap sebuah realitas yang telah dikonvensikan oleh suatu masyarakat pemakai bahasa. Kata makan memiliki referen, yakni suatu aktivitas/kegiatan memasukkan sesuatu/benda tertentu ke dalam mulut. Pensil, pena, merujuk pada alat untuk menulis. Bandingkan dengan kata akan, sedang, bahkan, lalu, selanjutnya. Kata-kata tersebut tidak memiliki referensi makna. Mereka hanya memiliki fungsi atau tugas tertentu. Semua kata tugas dan konjungsi tergolong pada jenis kata nonreferensial.

Berdasarkan klasifikasi jenis maknanya, kosakata siswa kelas rendah tampak pada diagram 3.

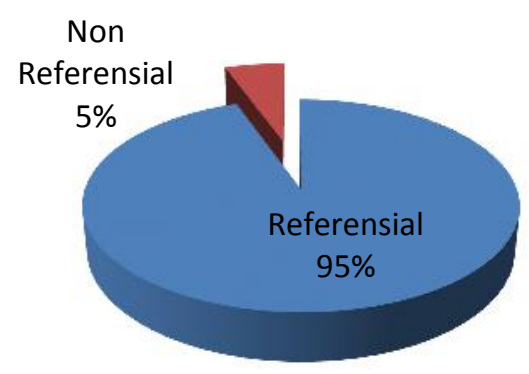

\section{Diagram 3. Jenis Makna Kata Siswa SD}

Dalam kenyataan berbahasa, kata-kata referensial memang jauh lebih banyak dari katakata nonreferensial. Menurut Hurlock (2009:153) kosakata yang harus dikuasai anak-anak usia 6-13 tahun (SD) ada dua jenis, yakni kosakata umum dan kosakata khusus. Kosakata umum, mencakup kata-kata umum yang digunakan manusia untuk berkomunikasi, yakni kata kerja, kata benda, kata sifat, kata keterangan, kata perangkai atau kata ganti orang. Kosakata khusus merupakan kata-kata khusus yang meliputi hal-hal tertentu seperti kosakata waktu, warna, uang, kosakata rahasia, kosakata populer, dan kosakata makian.

\section{Kosakata Siswa Kelas Rendah Berdasarkan Medan Makna}

Pengklasifikasian medan makna ini mengacu pada medan makna sebagaimana yang dikemukan Mahsun (2005:299-318). Menurutnya, medan makna terklasifikasi ke dalam 18 jenis, yakni: 1) Bagian tubuh (mata, alis, kumis, dll); 2) Kata ganti, sapaan, dan acuan (laki-laki, mas, bapak,); 3) Kekerabatan (abang, sepupu, besan, menantu, kakek); 4) Kehidupan Desa/masyarakat (arisan, juru tulis, kawin, bertunangan, kematian, kenduri); 5) Rumah dan bagian-bagiannya (atap, dapur, kandang, atap, dapur, kandang, gereja, pagar); 6) Peralatan dan perlengkapan (bajak, bantal, pisau, kail, keranjang); 7) Makanan dan minuman (bubur, cendol, gule); 8) Tanaman dan pepohonan (alang-alang, bunga melati, batang, bukuh, labu); 9) Binatang (kucing, kucing, kerbau, monyet); 10) Alam: musim, keadaan, benda, arah (arus, barat, bintang, besi, bukit, dini hari, ladang); 11) Penyakit dan Pengobatan (demam, tuli, bisul); 12) Perangai, Sifat, Warna (boros, angkuh, cantik, bijaksana, abu-abu, merah); 13) Mata Pencaharian (algojo, kuli, guru, pelawak, gembala); 14) Pakaian dan Perhiasan (anting, baju, sendal); 15) Permainan (layangan, gundu, 
gasing); 16) Gerak dan kerja (ambil, angkat, ayun, asuh); 17) Kata bilangan (delapan, seribu, ketga, seikat); 18) Kata Tugas (akan, atau, di, dari, besok, jarang).

Berdasarkan parameter di atas, medan makna kosakata siswa kelas rendah tergambar seperti dalam diagram 4.

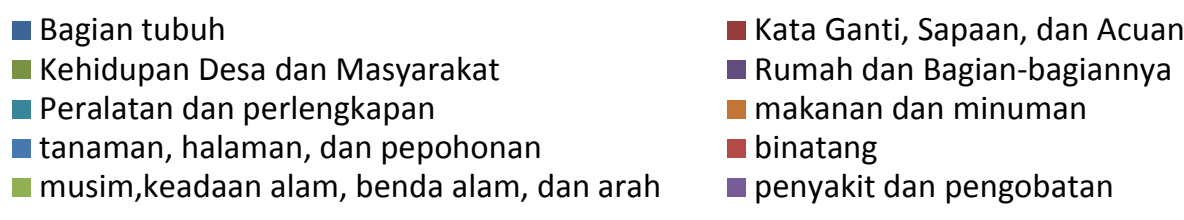

$0 \%$

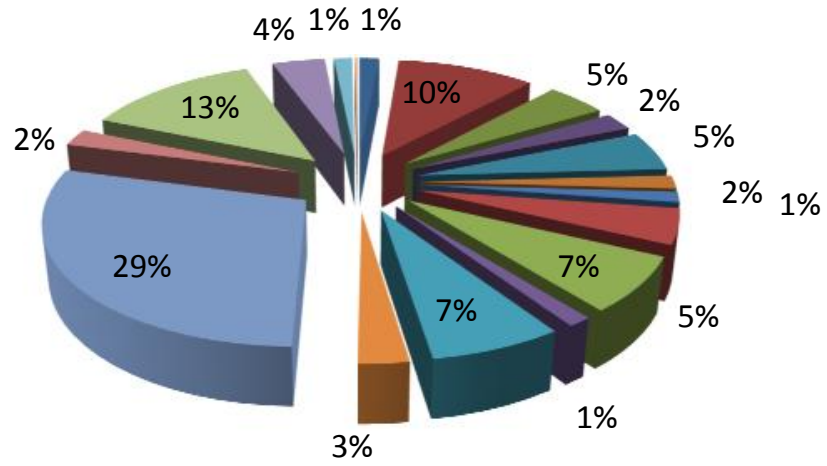

\section{Diagram 4.Medan Makna Kata Siswa SD}

Beberapa poin dari hasil penelitian ini sebagian ada yang mengukuhkan teori. Misalnya, temuan Gentner (1982), Bloom, dkk. (1993); Tardif (1995) menunjukkan bahwa anak-anak terlebih dahulu menguasai nomina sebelum verba. Ternyata hasil penelitian ini pun menunjukkan hal yang sama. Demikian juga dalam hal kenuniversalan semantik yang mengacu pada prinsip here and now. Ternyata anak-anak menunjukkan penguasaan kosakata yang objeknya berada di sekeliling mereka (here) dan yang saat ini ada (now). Siswa yang berasal dari kota dan sehari-hari bersentuhan dengan teknologi, bahkan menampilkan kosakata-kosakata yang dianggap canggih bagi anak seumurannya, misalnya kata didonlod (maksudnya download), brosing, akses, ceting, dll.. Sebaliknya, anak-anak dari sekolah-sekolah yang agak pinggiran justru menampilkan kosakata-kosakata yang dekat dengan kehidupan mereka, misalnya tentang mancing, sawah, ikan, kerbau, dan lain-lain.

Apa implikasi dari data hasil penelitian di atas? Bahasa dan pikiran memiliki kesalingterkaitan. Dardjowijoyo (2010) menyitir temuan Boas yang mengatakan bahwa cara berpikir seseorang dipengaruhi oleh struktur bahasa yang mereka pakai. Penguasaan kosakata mempengaruhi cara berpikir dan kreativitas siswa dalam proses pembelajaran bahasa sehingga penguasaan kosakata dapat menentukan kualitas seorang siswa dalam berbahasa (Kasno, 2004: 1). Bahasa membimbing para penggunanya untuk melihat dan mengkategorikan sesuatu dalam wujud kekayaan kosakata. Misalnya, bahasa Sunda memiliki beberapa kategori untuk kata nasi, yakni: pare, gabah, serah, beas, beunyeur, remeh, kerak liwet; sementara bahasa Inggris hanya memiliki satu kata saja, yakni rice. Di samping itu, dalam praktik pemakaiannya, kategori-kategori kata dimaksud bukan saja dipengaruhi oleh pikiran pengungkapnya, juga dipengaruhi oleh budaya masyarakat di mana si pengguna itu tinggal. Pandangan yang menyatakan bahwa bahasa mempengaruhi cara berpikir para penuturnya dinamakan hipotesis relativitas linguistik. 
Hipotesis ini harus menjadi pertimbangan para praktisi pendidikan dalam memanfaatkan hasil penelitian ini. Sebagaimana dijelaskan oleh Boas, terdapat tiga simpulan yang harus dicamkan berkenaan dengan hipotesis ini. Pertama, bahasa mengklasifikasikan pengalaman dan pengalaman itu tidak berbatas. Kedua, bahasa yang berbeda-beda mengklasifikasikan pengalaman dengan cara yang berbeda pula. Ketiga, fenomena linguistik bersifat unconscious karena produksi ujaran bersifat otomatis.

\section{SIMPULAN DAN SARAN}

Meskipun dianggap kurang representatif, namun hasil penelitian tentang pemetaan kosakata ini paling tidak dapat memberikan gambaran awal tentang potret kosakata siswa sekolah dasar yang dapat dijadikan input bagi berbagai pihak terkait yang berhubungan dengan dunia pendidikan dan pengajaran di sekolah dasar. Para penulis buku teks dapat memanfaatkan hasil penelitian ini untuk menyediakan buku teks yang tingkat keterbacaannya sudah disesuaikan dengan kosakata siswa SD. Demikian juga dengan guru yang sehari-hari dituntut untuk dapat berinteraksi dengan siswa secara komunikatif perlu memahami karakteristik kosakata anak usia SD. Semoga hasil penelitian ini bermanfaat.

\section{DAFTAR RUJUKAN}

Alwi, H., dkk.2003. Tata Bahasa Baku Bahasa Indonesia. Jakarta: Balai Pustaka.

Benedict, H. 1979. "Early Lexical Development: Comprehension and Production". Journal of Child Language 6, 96-151. Oxford: Blackwell.

Bloom, L. 1998. Language acquisition in its developmental context.

Bloom, L. 1993. Language Aquisition. Online http://psycnet.apa.org/psycinfo/2005-01927006 diakses Desember 2015

Chaer, A. 1994, 2007. Linguistik Umum. Jakarta: Rineka Cipta.

Chaer, A. 2009. Psikonguistik: Kajian Teoretik. Jakarta: Rineka Cipta.

Chomsky, N. 1999. Derivation by phase. Cambridge, MA: MIT.

Comrie, B. 1989. Language Universals and Linguistic Typology 2nd.ed. USA: The University of Chicago Press.

Dardjowijoyo, S. 2010. Psikolinguistik Pengantar Pemahaman Bahasa Manusia. Jakarta: Yayasan Obor Indonesia.

Fenson, L.et.all. 2001. Variability in Early Communicative Development. Monographs of the Society of Research in Child Development. Serial No. 242,59.

Gentner, D. 1982. "Why nouns are learned before verbs: Linguistic Relativity versus Natural Partitioning". In S. Kuczaj (Ed.). Language Development: Language, Cognition, and culture (pp. 301-334). Hillsdale, NJ: Erlbaum.

Harjasujana, AS. \& Mulyati. Y. (1995). Materi Pokok Membaca. Jakarta: Universitas Terbuka.

Hurlock, E.B. 2009. Psikologi Perkembangan.Jakarta: rlangga

Kasno. 2004. Kamus sebagai Sumber Rujukan dan Pengajaran Kosakata. Jakarta: Pusat Bahasa

KBBI. 2016 (online). Kamus Besar BahasaIindonesia. Jakarta: Badan Bahasa.

Labov, W. 1994. Principle of Linguistic Change. Volume 1: internal factors. London, USA: Cambridge, MA

Mahsun. 2005. Metode Penelitian Bahasa. Jakarta: PT Raja Grafindo Persada. 
Mar'at, S. 2005. Psikolinguistik: Suatu Pengantar. Bandung: Refika Aditama.

Peters, A.M. 1995. "Strategies in the Acquisition of Syntax". Handbook of Language Acquisition, ed. by P. Fletcher \& B. MacWhinney. Oxford: Blackwell.

Ramlan, M. 1985. Morfologi Suatu Tinjauan Deskriptif. Yogyakarta: C.V. Karyono.

Roberts, Theresia A. 2014. Not so silent after all.Examination and Analysis of the Silent Stage in Childhood Second Language Acquisition.Journal Early Childhood Research Quarterly (29), pp 22-40, diakses 11 November 2016.

Tardif, T. 1996. Nouns are not always learned before verbs: Evidence from Mandarin Speakers' Early Vocabularies. Developmental Psychology 32 (3), 492-504.

Vladimir M. Smokotin and Galina I. Petrova .2015. The Quest for a Universal Language throughout Human History. Journal Procedia - Social and Behavioral Sciences 200. pp 107 - 113, diakses 5 November 2016.

Wasik, Barbara A. 2016. Book Reading and Vocabulary Development: A Systematic Review. Journal Early Childhood Research Quarterly (37), pp 39-57, diakses 30 Desember 2016.

Zuchdi dan Budiasih. 1996. Pendidikan Bahasa dan Sastra Indonesia di Kelas Rendah. Jakarta: Depdikbud. 